Bangladesh J. Bot. 37(2): 195-198, 2008 (December)

- Short communication

\title{
PHYSALIS ANGULATA L. (SOLANACEAE) - A NEW ANGIOSPERMIC RECORD FOR BANGLADESH
}

\author{
Nahid Sultana ", M.A. Hassan, Momtaz Begum and Mahbuba Sultana \\ Department of Botany, University of Dhaka, Dhaka-1000, Bangladesh
}

Key words: Physalis angulata, New record, Bangladesh

\begin{abstract}
Physalis angulata L., an annual herb, belonging to the family Solanaceae, has been described and illustrated as a new record for Bangladesh.

Physalis, a genus of the family Solanaceae consisting of about 100 species, mainly distributed in tropical and temperate America, but some of the species have a world-wide distribution. Physalis angulata L. and Physalis minima L. are widely spread as weeds in the Old World, probably as post-Columbian introductions (van Valkenburg and Bunyapraphatsara 2002).

In Bangladesh, Physalis angulata has long been misidentified as $P$. minima L., a common weed of fallow lands, waste lands and crop fields. After a critical examination this species has been correctly identified as $P$. angulata $\mathrm{L}$. This species was not reported previously from the area now under Bangladesh. Thus it is recorded here for the first time for the country.

A detailed taxonomic description and illustrations of the species are prepared on the basis of living collections preserved at the Salar Khan Herbarium, D.U. (DUH) and Bangladesh National Herbarium (DACB).
\end{abstract}

Physalis angulata L., Sp. Pl.: 183 (1753).

(Fig. 1)

English names: Gooseberry, Hogweed, Balloon Cherry; Local name: Fotka.

An annual herb, $10-100 \mathrm{~cm}$ tall; stem hollow, quadrangular, lower branches sometimes prostrate and rooting at the nodes, green, glabrous. Leaves simple, alternate, ovate, acute, margins irregularly toothed, petioles $0.5-4.0 \mathrm{~cm}$ long, lamina $2.0-6.7 \times 1.0-3.5 \mathrm{~cm}$, slightly hairy. Inflorescence solitary, axillary. Flowers pedunculate, peduncles c $1.3 \mathrm{~cm}$ long, greenish-chocolate, glabrous, complete, bisexual, regular, actinomorphic, hypogynous. Sepals 5, gamosepalous, flowering calyx c $0.4 \mathrm{~cm}$ long, greenish-violet, margin slightly hairy, fruiting calyx c $3 \mathrm{~cm}$ long, green with purple ribs, glabrous. Petals 5, gamopetalous, pale yellow, with or without dark spots at inner surface, spots chocolate, slightly hairy. Stamens 5, epipetalous, basifixed, oblong, filaments c $0.4 \mathrm{~cm}$ long, light green, glabrous, anthers 2-celled, entirely pale blue, c $0.2 \mathrm{~cm}$ long. Carpels 2 , syncarpous, style 1, c $0.5 \mathrm{~cm}$ long, off-white, glabrous; stigma 1, light green, glabrous; ovary 2celled, c $0.2 \times 0.2 \mathrm{~cm}$, ovules many in each cell, light green, glabrous. Fruit a globose berry, enveloped in the bladder-like enlarged calyx. Seeds many, brown. Flowering and fruiting: Almost throughout the year.

Chromosome number: $2 \mathrm{n}=24,48$ (Fedorov 1969).

Habitat: Sunny to somewhat shaded fields, gardens, wastelands, fallow fields, along roadsides, in open forests and forest margins.

Distribution: Native to tropical America, now distributed pantropically, including Malaysia. In Bangladesh, it occurs throughout the country.

*Corresponding author. E-mail: <nahid_botany@yahoo.com>. 
Economic uses: In Malaysia, the aerial parts, including the fruits, are used to cure digestive and intestinal problems and various skin problems such as sores, boils and cuts. In Papua New Guinea, constipation is relieved by drinking a decoction of the leaves. The sap of the leaves in water is taken as an abortifacient, although their use to treat sterility is also mentioned. The fruit is eaten as a snack and the leaves as a salad, although the taste is bitter (van Valkenburg and Bunyapraphatsara 2002).

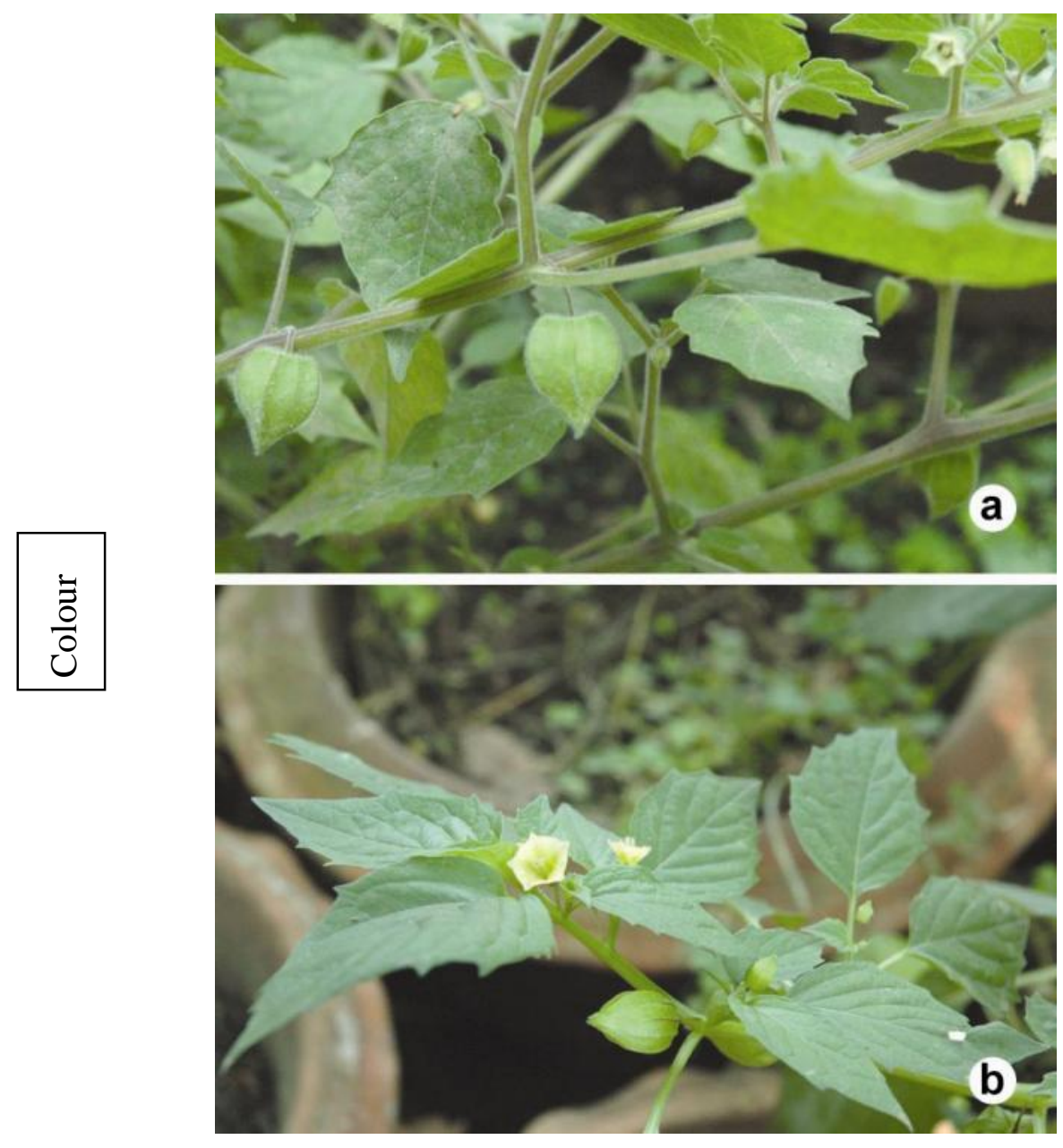

Fig. 1. (a) Physalis minima L. (Habit), (b). Physalis angulata L. (Habit).

Specimens examined: Bagerhat: Bagmara-Rupsa, 06.03.1985, A.M. Huq and M.K. Mia H. 6857 (DACB); Bandarban: Bandarban to Chimbuk, 01.12.1999, Khan, Mia, Rashid and Alam K. 10155 (DACB); Ruma, 05.12.2007, Bushra, Habib and Mofiz B. 582 (DACB); Barguna: Barguna-Amtuli, 19.03.1989, Huq, Mahfuz, Matiur and Mia H. 9152 (DACB); Bogra: Mohasthangar, 22.08.1989, Mia, Rahman, Mahbuba and Rezia M. 2207 (DACB); Chittagong: Himchori, Dhua Palang Range, 17.05.2006, Bushra, Habib and Mofiz B. 53 (DACB); Bariadhala Range, Bariadhala towards Hazarikhil, 24.06.1993, Mia, Rahman, Rezia and Momtaz M. 3277 (DACB); Dhaka: Botanical Garden, Dhaka University, 10.05.2007, Nahid Sultana 23 (DUH); 
Dhaka University Campus, 15.03.1997, Mahbuba and Rezia R.K. 1256 (DACB); Dinajpur: Khansama Upazila, Hossainpur, 24.08.2008, Mia M 4160 (DACB); Kantanagar, 19.10.1976, Huq, Rahman and Mia H. 2890 (DACB); Faridpur: Goalando, 16.06.1981, Mia, Huq, Halim and Begum M. 523 (DACB); Jessore: Keshabpur, 30.08.1983, Huq, Mia and Mahbuba H. 6035 (DACB); Jhalakathi: Kaukhali, 04.03.1985, A.M. Huq and M.K. Mia H. 6768 (DACB); Khulna: Jatrapur, Shatgambuz, 16.06.1982, A.M. Huq 5597 (DACB); Nilphamari: Nilphamari-Saidpur, 03.12.1985, Khan, Huq and Mia K. 7505 (DACB); Nowabganj: Rahanpur River Bank,

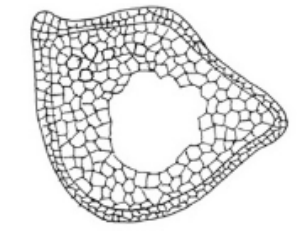

a

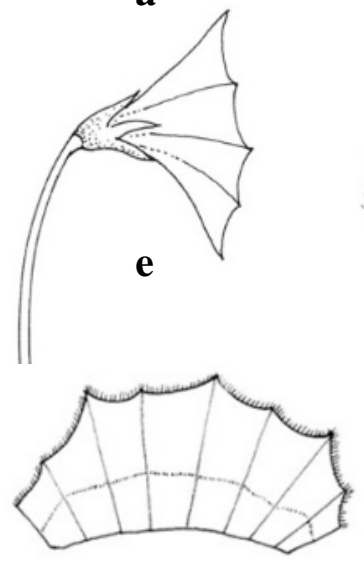

i

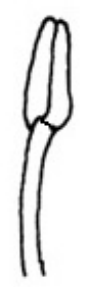

m

Physalis angulata $\mathrm{L}$.

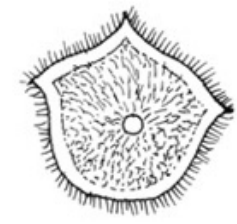

b
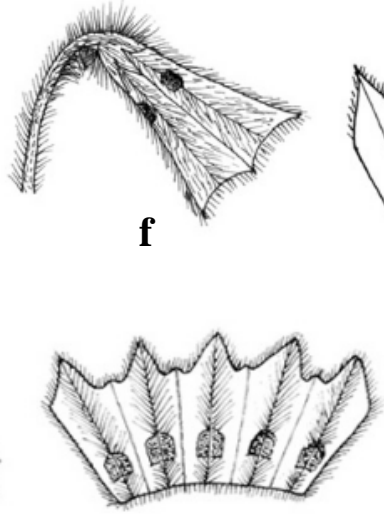

j

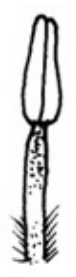

n

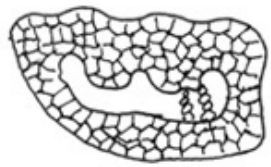

c
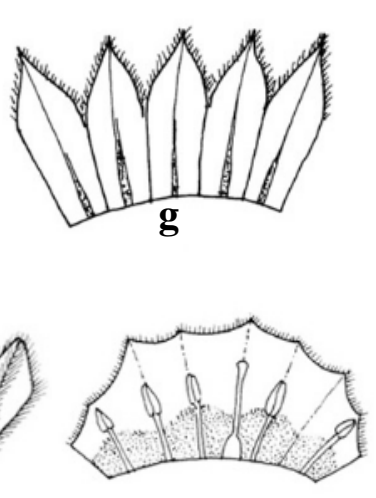

$\mathbf{k}$

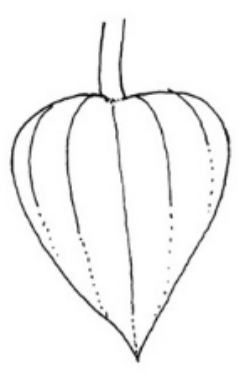

o

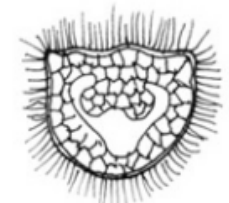

d
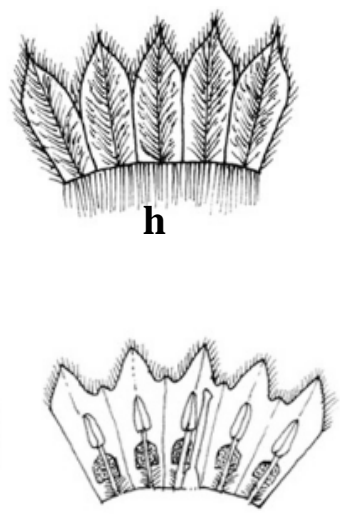

l

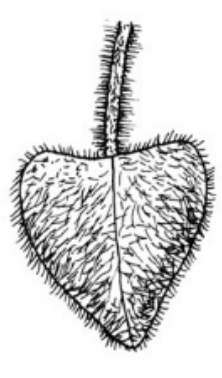

$\mathbf{p}$

Fig. 1. Morphological differences between Physalis angulata L. and P. minima L. (a, b) T.S. of stem $\times 3$, (c, d) T.S. of petiole $\times 4$, (e, f) Flower $\times 2$, (g, h) Dorsal surface of sepals $\times 4$, (i, j) Dorsal surface of petals $\times 2,((k, 1)$ Ventral surface of petals $\times 2,(m, n)$ Stamen $\times 4,(o, p)$ Fruit $\times 1$.

02.09.2002,Rezia, Momtaz, Bushra and Harun R.K. 3962 (DACB); Nachol Proper, 04.09.2002, Rezia, Momtaz, Bushra and Harun R.K. 3847 (DACB); Panchagarh: Chanspara, 01.07.1998, Mia, Nasir, Mosharraf and Harun M. 3997 (DACB); Patuakhali: Galachipa, 13.03.1982, Rahman 
and Mia R. 1326 (DACB); Kalapara, 23.07.98, Mahbuba Sultana 87; Rajshahi: Rajshahi University Campus, 09.12.1972, A.M. Huq 503 (DACB); Rangpur: Saidpur Railway Officer's Colony, 15.10.1976, Huq, Rahman and Mia H. 2625 (DACB); Sunamganj: Nurpur, 26.05.1992, Khan et al. K. 8720 (DACB); Sylhet: Jaflong, 28.04.2008, Nahid Sultana 24 (DUH); New Samanbagh Tea Estate Patharia, 27.03.1981, Khan, Zaman and Aziz K. 6194 (DACB); Tangail: Madhupur, 29.03.1988, A.M. Huq 73 (DACB); Madhupur, Chunia, 15.10.1989, M.K. Mia 228 (DACB).

$P$. angulata $\mathrm{L}$. is closely related to $P$. minima $\mathrm{L}$., but can easily be differentiated on the basis of the characters mentioned in the text and shown in Fig. 2.

Figure was constructed based on the studies of live specimens growing in Dhaka University Botanical Garden. The specimen identified as P. minima L. was originally collected from Patuakhali by Mahbuba Sultana.

\section{References}

Fedorov, A.A. 1969. Chromosome Numbers of Flowering Plants. Academy of Science of USSR, Moscow. pp. 926.

van Valkenburg, J.L.C.H. and N. Bunyapraphatsara. (Eds.). 2002. Plant Resources of South-East Asia No. 12(2). Medicinal and Poisonous Plants 2. Prosea Foundation, Bogor, Indonesia. pp. 782.

(Manuscript received on 16 October, 2008; revised on 27 October, 2008) 